\title{
Decreased Calcium Tolerance in Nongoitrous Cretins
}

\author{
Constantine S. Anast ${ }^{[30]}$ and Richard A. Guthrie \\ Department of Pediatrics, University of Missouri School of Medicine, Columbia, Missouri, USA
}

\begin{abstract}
Extract
Response to an exogenous calcium load was studied in 7 thyroid-treated sporadic nongoitrous cretins and in 16 normal children. An intravenous infusion of $10 \mathrm{mg} / \mathrm{kg}$ of body weight of calcium as calcium gluconate was infused over a 3-hr period. Serum samples obtained before and at 1.5, 3, 3.5, 4, 5, and $7 \mathrm{hr}$ after the start of the infusion were analyzed for calcium, magnesium, and phosphorus. The base-line calcium, magnesium, and phosphorus values in serum did not differ significantly in the thyroidtreated cretins and in normal children. The infusion of calcium did not alter magnesium levels and no consistent changes were noted in phosphorus levels in either group. Mean increments in calcium levels, however, were significantly greater in the cretins at $1.5,3,3.5$, and $4 \mathrm{hr}$ after the start of the infusion. The response to calcium infusion in two children with a thyroid-iodine organification defect was similar to that seen in the normal children.
\end{abstract}

\section{Speculation}

It is suggested that the impaired ability of the thyroid-treated nongoitrous cretins to counteract experimentally induced hypercalcemia is the result of calcitonin deficiency.

\section{Introduction}

In the past it was believed that major endocrine control of calcium homeostasis was exerted by the parathyroid glands. The recent discovery $[6,13]$ and isolation of the thyroid hypocalcemic factor, calcitonin (thyrocalcitonin), however, has focused attention on the thyroid gland as the site of a possible second major endocrine system that is important in calcium homeostasis.

Studies in patients as well as with experimental animals have shown that the intact thyroid gland protects against or counteracts experimentally induced hypercalcemia, presumably by secreting calcitonin $[2,11,12$, $21,23,24]$. Because calcitonin is clearly present in human thyroid tissue [18], the present investigation was undertaken in an effort to obtain physiologic evi- dence for the secretion of this hypocalcemic factor by the thyroid gland of children. The study was designed to observe whether thyroid-treated sporadic nongoitrous cretins differed from normal children in their response to acute calcium loads.

\section{Case Material}

Seven thyroicl-treated nongoitrous cretins (3.5-14.5 years of age) and 16 normal children (17 months-15 years of age) were the subjects of this study. Before therapy all of the cretins were severely hypothyroid and ${ }^{131}$ I uptake over the neck, measured from the base of the tongue to the sternal notch, was $3 \%$ or less. In five of the seven hypothyroid children, a salivary to blood ${ }^{131}$ I ratio was determined to rule out the possibility of an intact thyroid gland with an iodine trap- 
ping defect. At the time of the study the cretins were all euthyroid as judged by clinical appearances, rates of growth, and presence of normal serum proteinbound iodine levels. The children had received thyroid medication for periods ranging from 8 months to 13 years.

The normal group consisted of children admitted for elective surgery and children followed in the well child clinic at the University of Missouri Medical Center. The normal children were not receiving medication and there was no evidence in any of a chronic illness or endocrine disturbance. All of the subjects of the study were ambulatory.

Two children with a thyroid-iodine organification defect were also investigated. Diagnosis of an iodine organification defect was established by demonstration of a normal thyroid ${ }^{131} I$ uptake and a greater than $35 \%$ release of ${ }^{131}$ I following administration of potassium thiocyanate. Similar to the nongoitrous cretins, the children with an iodine organification defect were under treatment with thyroid medication and were cuthyroid at the time of the study.

\section{Materials and Methods}

The children received a low calcium diet for $48 \mathrm{hr}$ and thyroid medication was withheld for $24 \mathrm{hr}$. No breakfast was taken on the day of the test. An intravenous infusion of $10 \mathrm{mg} / \mathrm{kg}$ of body weight of calcium as calcium gluconate was administered in $150-200 \mathrm{ml}$ of $5 \%$ glucose in water over a 3 -hr period. Blood samples were taken immediately before and at 1.5, 3, 3.5, 4, 5, and $7 \mathrm{hr}$ after the start of the infusion. The serum was analyzed for calcium and magnesium by atomic absorption spectrophotometry and for inorganic phosphorus by the Fiske-Subbarow method [8] adapted to the Technicon AutoAnalyzer.

\section{Results}

Base-line calcium, magnesium, and phosphorus levels in serum did not differ significantly in thyroid-treated cretins and in normal children (Table I). Infusion of calcium did not alter the magnesium levels and no consistent changes were noted in phosphorus levels in either group.

Figure 1 reveals the patterns of response observed in calcium levels induced by infusion of calcium in thyroid-treated cretins and in normal children. The change in calcium level was plotted against the time in hours after start of the infusion. It can be seen that, in most of the normal children and in all of the thyroid-
Table I. Base-line calcium, magnesium, and phosphorus levels in serum in thyroid-treated cretins and normal children

\begin{tabular}{lcr} 
& \multicolumn{1}{c}{ Serum levels, $\mathrm{mg} / 100 \mathrm{ml}$} \\
\hline Normal $(16)^{1}$ & $\begin{array}{c}\text { Thyroid-treated } \\
\text { cretins }(7)\end{array}$ \\
\hline Calcium & $10.5 \pm 0.20^{2}$ & $10.7 \pm 0.16$ \\
Magnesium & $2.2 \pm 0.05$ & $2.2 \pm 0.07$ \\
Phosphorus & $4.4 \pm 0.20$ & $4.7 \pm 0.03$
\end{tabular}

${ }_{1}$ Numbers in parentheses indicate number of subjects.

${ }^{2}$ Mean $\pm \mathrm{SEM}$

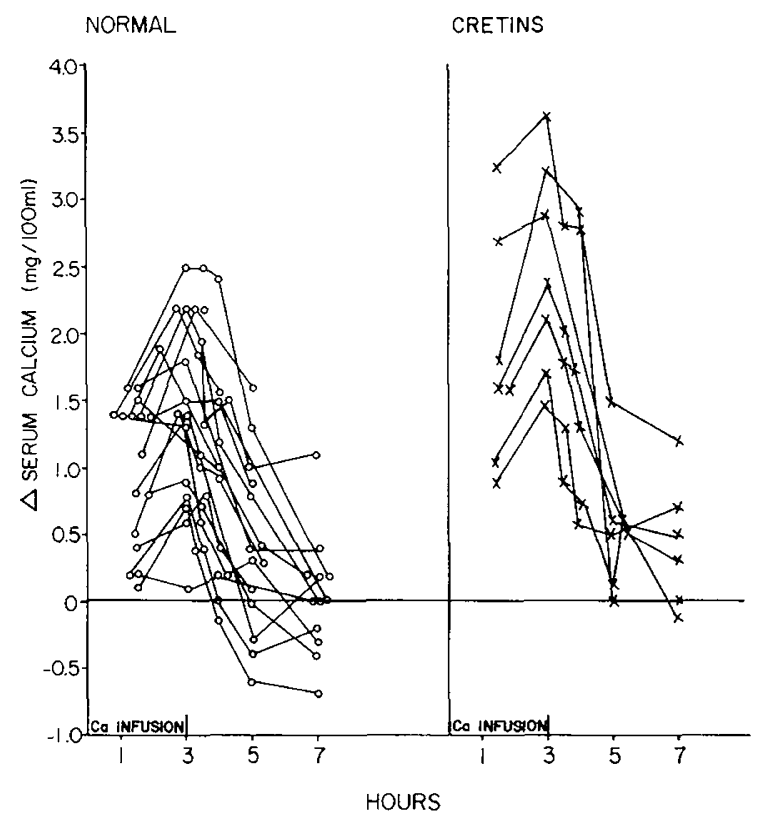

Fig. I. Response of 7 thyroid-treated nongoitrous cretins and 16 nomal children to calcium infusion. An intravenous infusion of calcium as the gluconate salt, $10 \mathrm{mg} / \mathrm{kg}$ of body weight, was administered over a 3 -hr period.

treated cretins, calcium levels increased above base line at $1.5 \mathrm{hr}$, then continued to rise to reach a peak at 3 hr, at the time of the completion of the infusion, and then declined toward base-line levels or lower during the next $4 \mathrm{hr}$. Of interest was the variability in the magnitude of changes in calcium levels observed within each group. Although there is some overlap, it is evident that there was a quantitative difference in the response of the two groups reflected by the predominantly higher curves found among the thyroidtreated cretins.

In Figure 2 mean increments in calcium lcvels above base line are compared in the two groups of children at each of the time periods studied. Mean increases in calcium levels were significantly greater in the cretins at $1.5,3,3.5$, and $4 \mathrm{hr}$ after the start of the infusion. 


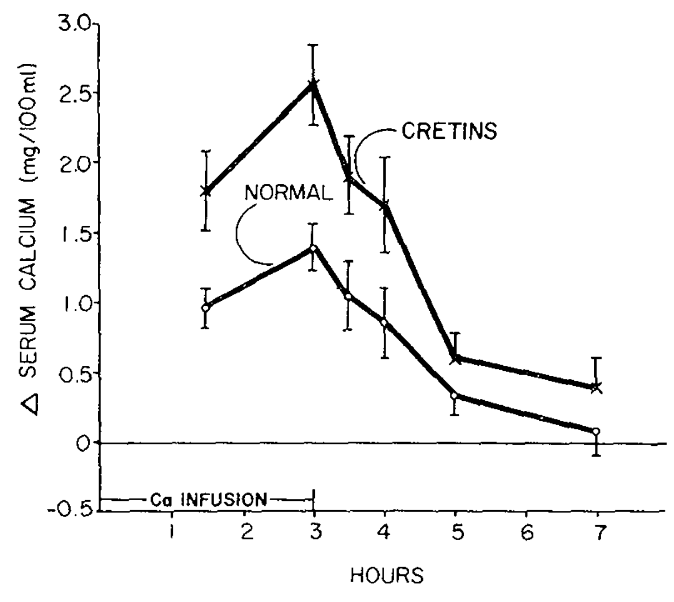

Fig. 2. Mean change above base line in scrum calcium level at each of the time periods studied duxing and after a calcium infusion in 7 thyroid-treated nongoitrous cretins and in 16 normal children. Vertical bars indicate \pm se.r. I)ifferences were significant at the following times: $1.5 \mathrm{hr}, P<0.01 ; 3 \mathrm{hr}, P<0.0 \mathrm{I} ; 3.5$ hr, $P^{\prime}<0.05 ; 4$ hr, $P<0.05$. $P$ values according to Fisher's Student $t$ test.

The greatest difference was observed at 3 hr when the mean increase in calcium level was $2.56 \mathrm{mg} / 100 \mathrm{ml}$ in the cretins compared with $1.46 \mathrm{mg} / 100 \mathrm{ml}$ seen in the normal children. Although the mean changes in calcium levels of cretins were still greater at 5 and $7 \mathrm{hr}$, the differences from the normal group were not statistically significant.

The patterns of response of two children with a thyroid-iodine organification clefect were similar to that found in the normal group.

\section{Discussion}

The results of this study indicate that thyroid-treated cretins counteract experimentally induced hypercalcemia less efficiently than normal children of similar ages. At least three factors need to be considered in attempting to explain this funding, namely, activity of parathyroid hormone, thyroxine, and calcitonin.

A greater than normal rise in calcium in serum following calcium infusion has been observed in hypoparathyroid patients $[11,14]$. The reason for this is not clear, although it has been speculated that prolonged hypocalcemia in these subjects might impair calcitonin release in acute experimental situations [14]. Base-line calcium levels were normal in our patients, however, and, furthermore, there is no evidence to indicate that parathyroid function is abnormal in thyroid-treated cretins.

There is evidence that both thyroxine and triiodothyronine increase rates of both bone formation and bone resorption and thereby are important in regulating the rate of bone remodeling [20]. Thyroid replacement in thyroidectomized rats influences the response to experimentally induced hypercalcemia, although it does not restore this response to normal [10]. Since the cretins were on thyroid replacement and were euthyroid at the time of the study, thyronine deficiency does not account for the impaired ability to counteract hypercalcemia.

Calcitonin deficiency appears to be the most likely explanation for the abnormal response to calcium infusion observed in the thyroid-treated cretins. Based on results of animal studies $[1,4,7,9,15,16]$, it would be expected that administration of a calcium load to normal children would stimulate calcitonin secretion which in turn would counteract hypercalcemia by inhibiting bone resorption. If calcitonin-secreting tissue were deficient or absent, a comparable calcium load would be expected to induce a relatively greater degree of hypercalcemia than was observed in the nongoituous cretins. As indicated earlier, an abnormal response to calcium infusion has been observed in thyroid-treated adults who had deficient functional thyroid tissue secondary to thyroidectomy, ${ }^{131}$ I therapy, or idiopathic spontaneous hypothyroidism [11, 21, 23, 24].

It was of interest that when the calcium infusion was stopped at $3 \mathrm{hr}$ the decrement seen in serum calcium per unit time over the following 2 -hr period was greater in the cretins than that observed in the normal children (Fig. 2). It appears likely, therefore, that the greater degree of hypercalcemia induced by the calcium infusion led to greater inhibition of parathyroid secretion in the cretins than in the control subjects. Furthermore, the higher plasma calcium levels may have resulted in greater urinary excretion or bone deposition of calcium, or both. Any one, or a combination, of these factors could have influenced the results and accounted for the greater decrement in calcium levels in these children in the postinfusion period.

The site of origin of calcitonin is the thyroid C cells, also called the light or parafollicular cells [3]. In view of the results of our study, it is pertinent to point out that the thyroid $\mathrm{C}$ cells, which secrete calcitonin, and the follicular cells, which secrete thyroxine, have different embryonic origins. The bulk of functional thyroid tissue (follicular cells) originates in the medial endoderm of the primitive pharyngeal foregut, and migrates caudad from the foramen cecum. The $\mathrm{C}$ cells, however, are derived from the ultimobranchial body which originates in the terminal branchial pouch [19]. During embryonic life, the ultimobranchial body fuses 
with the descending thyroid gland where it gives rise to a scattered population of $\mathrm{C}$ cells. In lower forms, such as fishes, reptiles, birds, and amphibians, the ultimobranchial body remains a distinct structure separate from the thyroid gland. In a recent study we have shown that there is a direct relation between dietary calcium and ultimobranchial body activity in the chicken [17].

If the abnormal response to calcium infusion in the present study reflects calcitonin cleficiency, it suggests that physiologically adequate $\mathrm{C}$ cells derived from the ultimobranchial bodly may not form or may not survive when there is congenital absence or marked deficiency of thyroid follicular tissue. Although studied in only a small number of patients, the normal response to calcium infusion in children with an iodine-organification defect suggests that the functional activity of the thyroid $\mathrm{C}$ cells is not compromised in this condition.

Currently, radioimmunoassay techniques are being developed for the determination of plasma calcitonin levels in humans $[5,22]$. Confirmation of the physiologic significance of calcitonin in explaining the results of the present report awaits future studies with a sensitive immunoassay procedure.

\section{Summary}

Calcium infusion induced a relatively greater degree of hypercalcemia in thyroid-treated nongoitrous cretins than in normal children of similar age. It is suggested that this may be the result of calcitonin deficiency in the nongoitrous cretins.

\section{References and Notes}

1. Alinpoulios, M. A., Golmhaber, P., and Munson, P. L.: 'Thyrocalcitonin inhibition of bone resorption induced by parathyroid homone in tissue culture. Science, 151:330 (1966).

2. Anast, C. S., Arnaud, C. D., Rasmussen, H., and Tenenhouse, A.: Thyrocalcitonin and the response to parathyroid hormone. J. Clin. Invest., 46:57 (1967).

3. Bussolati, G., ani PFarse, A. G. k.: Immmofluorescent localization of calcitonin in 'C' cells of pig and dog thyroid. J. Endocrinol., 37: 205 (1967).

4. Ciare, A. D., Cooptr, C. W., Duncin, T., and Orimo, H.: The direct measurement of thyrocalcitonin secretion rate in vivo. In: R. V. Talmage and B. F. Belanger: Parathyroid Hormone and Thyrocalcitonin (Calcitonin), p. 417 (Excerpta Mcdica foundation, Amsterdam, 1968).

5. Cl,ARK, M. B., BOYd, G. W., BYFIELd, P. G. H., ANd Foster, G. V.: A radio-immunoassay for human calcitonin M. Lancet, ii: $74(1969)$

6. Copl', D. H., Davidson, A. G. F., and Cheney, B. A.: Evidence for a new parathyroid hormone which lowers blood calcium. Proc. Can. Fed. Soc., 4: 17 (1961).
7. DiFTos, I. J., LEe, M. R., AND POTTS, J. T., Jk.: A radlioimmumoassay for thyrocalcitonin. Proc. Nat. Acad. Sci. U.S.A., 60: 293 (1968).

8. Jiske, C. H., AND SUbBakow, Y.: The colorimetric determination of phosphorus. J. Biol. Chem., 66: 375 (1925).

9. Frridman, J., AND Raisz, I. G.: Thyrocalcitonin: inhibitor of bone resorption in tissue culture. Science, 150: 1465 (1965).

10. GITTES, R. F., AND IRvin, G. L.: Roles of thyroxine and thyrocalcitonin in the response to hypercalcemia in rats. Fndocrinology, 79: 1033 (1969).

11. Hahnemann, S., AND FRIIS, T.: Latent parathyroid insufficiency following thyroidectomy. II. Effect of intravenous infusion of calcium upon the serum calcium. Acta Med. Scand., I77: $587(1965)$.

12. Hirscil, P. F., AND MUNson, P. L.: Importance of the thyroid gland in the prevention of hypercalcemia in rats. Endocrinology, 79: 655 (1966).

I3. Hirsch, P. F., Vori.kei., E. I., and Munson, P. L.: Thyrocalcitonin: hypocalcemic hypophosphatemic principle of the thyroid gland. Science, 1t6: 412 (1964).

14. Imbertson, H. K., Roche, A. H., and Pybus, J.: The thyroid and calcium homeostasis in man: evaluation by calcium infusion. Australas. Ann. Med., 16: 121 (1967).

15. Johnston, C. C., JR., AND DEISs, W. P., JR.: Inhibitory effect of thyrocalcitonin on calcium relcase in vivo and on bone metabolism in vitro. Endocrinology, 78: 1139 (1966).

16. Lke, M. R., Deftos, L. J., AND PotTs, J. 'T., JR.: Control of secretion of thyrocalcitonin in the rabbit as evaluated by xadioimmunoassay. Endocrinology, 82: 83 (1969).

17. Mulller, G. L., Anast, C. S., and Bretenbach, R. P.: Dictary calcium and the ultimobranchial body and parathyroid gland in the chicken. Amer. J. Physiol., 6: 218 (1970).

18. Nimer, R., Riniker, B., Maier, R., Byfield, P., Gudmundson, R. V., AND MacIntrre, I.: Human calcitonin. Nature, 200: 984 (1968).

19. Pearse, A. G. E., an'm Carvaliheira, A. I.: Cytochemical evidence for an ultimobranchial origin of rodent thyroid ' $\mathrm{C}$ ' cclls. Nature, $21+: 929$ (1967).

20. Rasmussin, H.: The parathyroids. In: R. H. Williams: Textbook of Endocrinology, p. 896 (W. B. Saunders Company, Philadelphia, 1968).

2I. Rigig, B. L., JONES, J. I., ANI ARNAUD, (. D.: Effect of calcium infusion on serum calcium levels in hypothyroidism. Metabolism, 17: 747 (1968).

22. Tasmjhan, A. H., Jr., Howland, B. G., Melvin, K. E. W., and Hı.,., C. S., Jr.: Immunoassay of calcitonin in human plasma. lifty-second Meeting of the Endocrine Society, St. Louis, Mo. $(1970)$.

23. Witmans, G. A., Hargis, G. K., Galloway, S. B., and HenDI:Rson, W. J.: Evidence for thyrocalcitonin in man. Proc. Soc. Exp. Biol. Med., 122: 1273 (1966).

24. Woonhouse, J. J. Y., AND BARnes, N. D.: The response of athyroidal paticnts to calcium infusion: evidence for an action of thyrocalcitonin. In: Calcitonin. Procedings of the Sympsium on Thyrocalcitonin and 'C' Cells, p. 36I. (William Heinemann Medical Books, Ltd., London, 1968).

25. Informed consent was obtained for the calcium infusion studies reported in this paper.

26. The authors acknowledge the skillful technical assistance of Mrs. Joan Folwell. 
27. Supported by Public Health Service Rescarch Grants nos. HD 02756 and AM 01351. The National Institutes of Health supported the Clinical Research Center with Grant no. FR 00287.

28. Dr. Anast is the recipient of Career Research Development Award no. HD-38654 from the National Institute of Child Health and Human Development.
29. Dr. Guthrie was supported by National Institutes of Health Training Grant no. AM 0.5110; He is presently Associate Professor of Pediatrics.

30. Requests for reprints should be addressed to: Constantrine $S$. ANAST, M.D., Department of Pediatrics, University Hospital, Columbia, Mo. 65201 (USA).

31. Accepted for publication January 13, 1971. 